\title{
COVID-19 Pandemic: Lessons from Peak Years of Influenza \& Suicide Deaths by Age in Ten Western Countries 1979-2016: An Alert for Psychiatry and Children's Services
}

\author{
Colin Pritchard1 (ㅇ, Anne Silk¹, Lars Hansen² \\ ${ }^{1}$ Faculty of Health \& Social Sciences, Bournemouth University, Poole, UK \\ ${ }^{2}$ Dept Psychiatry, University of Southampton, Southampton, UK \\ Email: cpritchard@bournemouth.ac.uk
}

How to cite this paper: Pritchard, C., Silk, A. and Hansen, L. (2021) COVID-19 Pandemic: Lessons from Peak Years of Influenza \& Suicide Deaths by Age in Ten Western Countries 1979-2016: An Alert for Psychiatry and Children's Services. Open Journal of Psychiatry, 11, 71-79.

https://doi.org/10.4236/ojpsych.2021.112007

Received: January 15, 2021

Accepted: April 5, 2021

Published: April 8, 2021

Copyright $\odot 2021$ by author(s) and Scientific Research Publishing Inc. This work is licensed under the Creative Commons Attribution International License (CC BY 4.0).

http://creativecommons.org/licenses/by/4.0/ (c) (i) Open Access

\begin{abstract}
Background: The IMF fears the COVID-19 pandemic will create an economic down-turn matching the Great Depression. More recent recessions have led to physical and mental health problems including suicide deaths of young adults (15 - 34). We aim to identify risk patterns of mortality by age from influenza and suicide mortality in peak years from 1979 to 2016 to see if there are lessons to be learned for policy makers and psychiatric services. Method: Using WHO mortality data for 1979-2016 peak years of influenza deaths and suicides are identified in ten Western countries. Death rates per million in each age-band are calculated for both sexes and the percentage of the total deaths accruing in each of five age-bands for influenza and suicides. Ratios of influenza to suicide by age in regard to rates and percentages of deaths indicate differential risk mortality and morbidity patterns. Results: Of the ten country's average Influenza deaths, $95 \%$ occurred in people over 55, including $80 \%-85 \%$ for the over 75 's. Conversely it was $59 \%$ of suicides occurred in peoples aged $<55$ years. Young adults $(15-34)$ influenza to suicide ratios were 1:12.1 and 35 - 54 years ratio 1:9.3. Discussion: IMF predicts major unemployment, which is likely to create mental health problems, including suicide as well as worsening child health outcomes linked to relative poverty. These wider inter-related factors should be considered by policy-makers and mental health services. The age patterns of risk of mortality point towards a cumulative summation of morbidity and mortality risks of the socio-economic consequences of the COVID pandemic.
\end{abstract}

\section{Keywords}

COVID-19, Influenza Deaths Suicide, Socio-Economic Consequences 


\section{Introduction}

The impact of the current COVID-19 crisis on both the individual and society is hard to overstate. The catastrophe relates in part to its virulent speed of spread and as yet, the lack of widespread human immunity, although the start of vaccination programmes promises to bring to an end the severest outcome of the pandemic. The daily death toll seems overwhelming with heart-breaking stories, resulting in governments making radical decisions. Inadvertently, these decisions may have consequences and long-term ramifications in other areas of public life. Self-evidently, the measures to isolate vulnerable people, protect frontline health staff and the welcome development of an effective vaccine are not in question, but the wider health consequences of the lockdown need to be considered, especially those related to mental health [1] [2] [3] [4] [5]. Indeed, it has long been known that times of recession are associated with increase in suicides, especially amongst young adult (15 - 34) and already leading suicide experts are expressing serious concern [6] [7] [8] [9] [10].

To gain some understanding of possible outcomes we draw upon age patterns of mortality that emerged in peak years of previous influenza epidemics between 1979 and 2016 juxtaposed with peak years of suicides. The latter are most strongly associated with periods of increased unemployment [6] [7] [8] [9] [10], interestingly there is already an emerging evidence of subsequent mental health problems and increased suicidal behaviour following viral epidemics [1]-[6]. Information on the current COVID-19 infections is beginning to be released and research from Wuhan in China found that older people, especially those with underlying health conditions, had substantially poorer outcomes and the over 75 's accounted for $80 \%$ of deaths [11].

Nonetheless, it must be noted that the majority of "ordinary" influenza and COVID-19 infected people recover, as did most COVID-19 victims in Wuhan [11]. However, even in Western countries people die from viral influenza and over the years the mortality of these viral infections fluctuated widely depending upon the viral mutant responsible for the epidemic.

For example, based upon WHO data, in this century the UK had four separate years when the influenza death rate was less than one per million $(<1 \mathrm{pm})[12]$. The lowest was in 2003 when just 84 people died compared to Britain's peak influenza death rate of 1989, when 2614 people died, giving an influenza death rate of $46 \mathrm{pm}$, which was fifteen times higher than the UK average of $3 \mathrm{pm}$ over the 1979-2015 period [12] clearly the present pandemic is far greater than the last peak.

Judging from the measures governments across the world have taken, the socio-economic impacts of the pandemic are likely be considerable as the IMF forecast this will be worst economic down-turn since the great depression [13]. This is a matter of grave concern because increased unemployment is strongly correlated to "mental behaviour disorder" problems des [6] [7] [8] [9] [10] [14] [15]. However, one feature not yet noted is what is an almost "hidden" statistic 
that even in Western countries is the continued association of relative poverty and poor child education and health outcomes. This is seen in a recent study of 21 Western countries to find a continued strong correlation between income inequality and child mortality 16 . Notwithstanding the advent of the vaccines the socio-economic impact on child health outcomes and mental health consequences are likely to continue to be negatively affected and looking at previous recessions, are likely to last for a number of years [3] [6] [10] [14] [15].

Consequently, using WHO data this study explores peak years of influenza deaths and suicides in ten Western countries [12] to identify any previous patterns of mortality that might be useful in understanding the present pandemic. It will help to highlight the risk of subsequent morbidity and mortality of the cumulative summation of the impact of the socio-economic consequences of the COVID-19 pandemic.

The focus upon differential risk by age might be considered to be "ageist" which we strongly refute as the aim is to simply look at what are normative age patterns of these two mortalities, which will give an indication of risk morbidity and mortality.

There is one working null hypothesis. That there will be no differences in the age-patterns of mortality of the peak years of either influenza deaths or suicides in the ten Western countries.

\section{Methodology \& Study Design}

This is a population-based study design utilising the latest available WHO mortality data [12]. The countries to be reviewed are Canada, France, Germany, Italy, Japan, Spain, the UK and the USA who have the largest populations of the Western countries. Plus Norway and Portugal because respectively, they have the highest and lowest income per capita of Western countries [13]. This allows a brief exploration of these exemplar countries to determine whether there is any marked variation between the most and least affluent Western countries and of the eight largest population of Western countries.

The focus is upon differential patterns of mortality by age to indicate risk levels and underlying morbidity, hence the use of influence to suicide ratios to demonstrate any proportional differences in the burden of mortality amongst the age groups. All mortality data is taken from WHO statistics, updated May 2018 and the viral mortality category is designated "Influenza" coded J10-J11 [13]. Total death rates per million ( $\mathrm{pm}$ ) for both sexes are calculated from the number of deaths, divided by the population. Deaths rates for the five age-bands are also calculated. These are children ( 0 - 14), young adults (15 - 34), adults (35 - 54), older adults (55 - 74) and the elderly (75+ years) based upon the numbers of deaths and the population of each age-band for the different peak years for influenza and suicide for each country.

We calculate the percentage of total deaths occurring in each age band by extracting the numbers of deaths in each age-band divided by the total number of that country's deaths to give a percentage, to determine any substantial differ- 
ences in age-related patterns of mortality and where the burden of mortality lies in the two different conditions.

Average influenza and suicide rates per million $(\mathrm{pm})$ are juxtaposed and ratios are calculated. Average percentage of total deaths of influenza and suicide for each age based is compared and ratios calculated.

Finally to place both influenza and suicide deaths in wider context the All causes of deaths are reported for the USA as representative of the other nations and the percentage of each age-band of total deaths are calculated to demonstrate normative patterns when not in a pandemic.

\section{Results}

1) Peak Influenza Years: Table 1 presents the range of influenza deaths of the peak years of each of the ten Western countries. It provides the numbers and rates of death per million $(\mathrm{pm})$ in each age-band. Plus the percentage of total deaths occurring in each age-band.

There is total consistency in All ten countries-the vast majority of deaths occurred amongst the over 75 's, averaging $80 \%$ of all deaths, whilst $55-74$ year olds accounted for a further average $15 \%$ of influenza deaths.

The non-pandemic normative All Causes of deaths in the USA reflected this percentage distribution $54.6 \%$ of deaths were in the $75+$ age band and a further $32.1 \%$ of $55-74$, thus $87 \%$ of all deaths were amongst $55-75+$ aged people. Thus overall, even at the peak of recent influenza deaths, from children to people aged up to 54, they accounted for just 5.1\% of all influenza deaths. Thus, these mortality patterns would seem to be the "normative" pattern of viral deaths, with older and elderly people, often with pre-existing co-morbidity, bearing the brunt of the toll.

It should be noted that after a perusal of all ten Western countries peak, Norway had the highest rate of influenza deaths reported between 1979 and 2016 at $67 \mathrm{pm}$ down to the lowest Germany at $8 \mathrm{pm}$ the overall average being $34 \mathrm{pm}$.

2) Suicide Peak Years: Table 2 shows that suicide patterns relating to age were entirely different to those of influenza. The overall average of the ten countries for suicide was such that children $(0-14)$ accounted for $0.8 \%$ of all deaths, young adults (15 - 34) $25 \%$, adults (35 - 54) 34\%, mature adults (55 - 74) $29 \%$ and the elderly $(75+) 12 \%$. Furthermore, suicide rates were far higher than the peak year influenza deaths in each country's age band, except for elderly.

Thus the majority of suicides, $59 \%$ were people aged below fifty-four, in stark contrast to the $95 \%$ of influenza death that happened to people aged fifty-five and above.

Peak suicides were highest in France at $226 \mathrm{pm}$ in 1986 down to $83 \mathrm{pm}$ in Italy in 1985 , the overall average being $148 \mathrm{pm}$.

3) Average Influenza to Suicide Ratios: Table 3 presents influenza to suicide death ratios by each age band. The contrast between average influenza to suicide percentages of deaths is markedly different. In terms of rates per million this pattern is of more younger suicides to influenza, with influenza to suicide ratios 
Table 1. Peak influenza year deaths by age \& percent of total influenza deaths by numbers and rates per million $(\mathrm{pm})$ in ten western countries [\% $55-75+$ years].

\begin{tabular}{|c|c|c|c|c|c|c|}
\hline $\begin{array}{c}\text { Country } \\
\text { Year }\end{array}$ & $\begin{array}{c}\text { Total } \\
\text { No's-pm }\end{array}$ & $\begin{array}{c}0-14 \\
\text { No's-pm }\end{array}$ & $\begin{array}{c}15 \text { - } 34 \\
\text { No's-pm }\end{array}$ & $\begin{array}{c}35 \text { - } 54 \\
\text { No’s-pm }\end{array}$ & $\begin{array}{c}55 \text { - } 74 \\
\text { No's-pm }\end{array}$ & $\begin{array}{c}75+ \\
\text { No's-pm }\end{array}$ \\
\hline Canada & $894-25 \mathrm{pm}$ & $2-0.3 \mathrm{pm}$ & $1-0.1 \mathrm{pm}$ & $7-0.8 \mathrm{pm}$ & $78-16 \mathrm{pm}$ & $675-421 \mathrm{pm}$ \\
\hline 2013 & $100 \%$ & $0.3 \%$ & $0.1 \%$ & $0.9 \%$ & $10 \%$ & $88 \%$ [98\%] \\
\hline France & $2942-55 \mathrm{pm}$ & $19-1.7 \mathrm{pm}$ & $17-1 \mathrm{pm}$ & $43-3 \mathrm{pm}$ & $372-40 \mathrm{pm}$ & $2490-735 \mathrm{pm}$ \\
\hline 1981 & $100 \%$ & $0.6 \%$ & $0.6 \%$ & $1.5 \%$ & $13 \%$ & $85 \%$ [98\%] \\
\hline Germany & $738-8 \mathrm{pm}$ & $12-0.9 \mathrm{pm}$ & $17-0.7$ & $24-1 \mathrm{pm}$ & $73-5 \mathrm{pm}$ & $612-107 \mathrm{pm}$ \\
\hline 1990 & $100 \%$ & $1.6 \%$ & $2.3 \%$ & $3 \%$ & $10 \%$ & $83 \%$ [93\%] \\
\hline Italy & $1354-24 \mathrm{pm}$ & $18-4 \mathrm{pm}$ & $16-0.9 \mathrm{pm}$ & $40-3 \mathrm{pm}$ & $231-32 \mathrm{pm}$ & $1048-355 \mathrm{pm}$ \\
\hline 1981 & $100 \%$ & $1.3 \%$ & $1.2 \%$ & $3 \%$ & $17 \%$ & $77 \%$ [94\%] \\
\hline Japan & $2262-18 \mathrm{pm}$ & $25-0.6 \mathrm{pm}$ & $15-0.4$ & $46-1.4 \mathrm{pm}$ & $164-9 \mathrm{pm}$ & $552-138 \mathrm{pm}$ \\
\hline 1982 & $100 \%$ & $3.1 \%$ & $1.9 \%$ & $6 \%$ & $20 \%$ & $69 \%$ [89\%] \\
\hline Norway & $288-67 \mathrm{pm}$ & $0-0 \mathrm{pm}$ & $0-0 \mathrm{pm}$ & $1-0.9 \mathrm{pm}$ & $27-36 \mathrm{pm}$ & $260-831 \mathrm{pm}$ \\
\hline 1993 & $100 \%$ & 0 & 0 & $0.3 \%$ & $9 \%$ & $90 \%$ [99\%] \\
\hline Portugal & $283-29 \mathrm{pm}$ & $16-6 \mathrm{pm}$ & $9-3 \mathrm{pm}$ & $8-3 \mathrm{pm}$ & $46-18 \mathrm{pm}$ & $204-523 \mathrm{pm}$ \\
\hline 1981 & $100 \%$ & $6 \%$ & $3 \%$ & $3 \%$ & $16 \%$ & $72 \%[86 \%]$ \\
\hline Spain & $2054-54 \mathrm{pm}$ & $19-2 \mathrm{pm}$ & $8-0.7 \mathrm{pm}$ & $36-4 \mathrm{pm}$ & $366-6 \mathrm{pm}$ & $1655-1034 \mathrm{pm}$ \\
\hline 1981 & $100 \%$ & $0.9 \%$ & $0.4 \%$ & $2 \%$ & $17 \%$ & $81 \%$ [98\%] \\
\hline UK 1989 & $2614-46 \mathrm{pm}$ & $7-0.6 \mathrm{pm}$ & $13-0.8 \mathrm{pm}$ & $34-2 \mathrm{pm}$ & $424-39 \mathrm{pm}$ & $2136-543 \mathrm{pm}$ \\
\hline \% Deaths & $100 \%$ & $0.3 \%$ & $0.5 \%$ & $1 \%$ & $16 \%$ & $82 \%$ [98\%] \\
\hline USA 2015 & $5325-16 \mathrm{pm}$ & $80-1.3 \mathrm{pm}$ & $29-0.7 \mathrm{pm}$ & $213-2.6 \mathrm{pm}$ & $993-14 \mathrm{pm}$ & $3933-197 \mathrm{pm}$ \\
\hline$\%$ deaths & $100 \%$ & $1.5 \%$ & $0.5 \%$ & $4 \%$ & $19 \%$ & $74 \%$ [93\%] \\
\hline USA \%All & $2,813,350$ & 31,786 & 92,240 & 249,938 & 903,616 & $1,535,794$ \\
\hline Deaths & $100 \%$ & $1.1 \%$ & $3.3 \%$ & $8.8 \%$ & $32.1 \%$ & $54.6 \%$ [87\%] \\
\hline \multicolumn{7}{|l|}{ Average } \\
\hline Influenza & $34 \mathrm{pm}$ & $2 \mathrm{pm}$ & $10 \mathrm{pm}$ & $21 \mathrm{pm}$ & $22 \mathrm{pm}$ & $488 \mathrm{pm}$ \\
\hline$\%$ deaths & $100 \%$ & $1.6 \%$ & $1 . \%$ & $2.5 \%$ & $15 \%$ & $80.1 \%$ [95\%] \\
\hline \multicolumn{7}{|l|}{ USA Flue: } \\
\hline All USA Death\% & 1.00 & 0.69 & 3.3 & 3.52 & 2.14 & 0.68 \\
\hline
\end{tabular}

Table 2. Peak suicide deaths by age in twelve western countries numbers and rates per million (pm). Ratios influenza to suicide [\% Deaths 55-75+years].

\begin{tabular}{ccccccc}
\hline $\begin{array}{c}\text { Country } \\
\text { Peak Year }\end{array}$ & $\begin{array}{c}\text { Total } \\
\text { No's-pm }\end{array}$ & $\begin{array}{c}\mathbf{0}-\mathbf{1 4} \\
\text { No's-pm }\end{array}$ & $\begin{array}{c}\mathbf{1 5}-\mathbf{3 4} \\
\text { No's-pm }\end{array}$ & $\begin{array}{c}\mathbf{3 5}-\mathbf{5 4} \\
\text { No's-pm }\end{array}$ & $\begin{array}{c}\mathbf{5 5 - 7 4} \\
\text { No's-pm }\end{array}$ & $\begin{array}{c}\mathbf{7 5 +} \\
\text { No's-pm }\end{array}$ \\
\hline Canada & $3755-151 \mathrm{pm}$ & $46-8 \mathrm{pm}$ & $1263-142 \mathrm{pm}$ & $1867-271 \mathrm{pm}$ & $626-165 \mathrm{pm}$ & $187-206 \mathrm{pm}$ \\
1983 & $100 \%$ & $1 \%$ & $33 \%$ & $50 \%$ & $17 \%$ & $5 \%[22 \%]$ \\
France & $12,529-226 \mathrm{pm}$ & $41-4 \mathrm{pm}$ & $2960-174 \mathrm{pm}$ & $3940-291 \mathrm{pm}$ & $3585-369 \mathrm{pm}$ & $2159-606 \mathrm{pm}$ \\
1986 & $100 \%$ & $0.3 \%$ & $24 \%$ & $31 \%$ & $29 \%$ & $17 \%[60 \%]$ \\
\hline
\end{tabular}




\section{Continued}

\begin{tabular}{|c|c|c|c|c|c|c|}
\hline Germany & $14,010-175$ & $32-2 \mathrm{pm}$ & $2894-121 \mathrm{pm}$ & $4627-211 \mathrm{pm}$ & $3845-247 \mathrm{pm}$ & $2612-469 \mathrm{pm}$ \\
\hline 1991 & $100 \%$ & $0.2 \%$ & $21 \%$ & $33 \%$ & $27 \%$ & $19 \%[46 \%]$ \\
\hline Italy & $4759-83 \mathrm{pm}$ & $15-1.4 \mathrm{pm}$ & $726-45 \mathrm{pm}$ & $1284-87 \mathrm{pm}$ & $1903-173 \mathrm{pm}$ & $781-254 \mathrm{pm}$ \\
\hline 1985 & $100 \%$ & $0.3 \%$ & $15 \%$ & $27 \%$ & $40 \%$ & $16 \%[56 \%]$ \\
\hline Japan & $32,118-255 \mathrm{pm}$ & $65-4 \mathrm{pm}$ & $5756-175 \mathrm{pm}$ & $11,175-331 \mathrm{pm}$ & $11,509-370 \mathrm{pm}$ & $3376-321 \mathrm{pm}$ \\
\hline 2003 & $100 \%$ & $1.5 \%$ & $18 \%$ & $\mathrm{~m} 35 \%$ & $\mathrm{~m} 36 \%$ & $11 \%[47 \%]$ \\
\hline Norway & $708-168 \mathrm{pm}$ & 7-9 pm & $250-219 \mathrm{pm}$ & $233-228 \mathrm{pm}$ & $168-211 \mathrm{pm}$ & $50-173 \mathrm{pm}$ \\
\hline 1988 & $100 \%$ & $0.9 \%$ & $35 \%$ & $33 \%$ & $24 \%$ & $7 \%[31 \%]$ \\
\hline Portugal & $1037-104 \mathrm{pm}$ & $17-7 \mathrm{pm}$ & $270-55 \mathrm{pm}$ & $341-141 \mathrm{pm}$ & $315-198 \mathrm{pm}$ & $94-218 \mathrm{pm}$ \\
\hline 1984 & $100 \%$ & $1.6 \%$ & $26 \%$ & $33 \%$ & $30 \%$ & $9 \%[39 \%]$ \\
\hline Spain & $3373-86 \mathrm{pm}$ & $14-2 \mathrm{pm}$ & $835-66 \mathrm{pm}$ & $850-86 \mathrm{pm}$ & 994-129 pm & $650-252 \mathrm{pm}$ \\
\hline 1997 & $100 \%$ & $0.4 \%$ & $25 \%$ & $25 \%$ & $30 \%$ & $19 \%[49 \%]$ \\
\hline UK & $5108-90 \mathrm{pm}$ & 5-0.7 pm & $1293-75 \mathrm{pm}$ & $1713-124 \mathrm{pm}$ & $1593-$ & $501-138 \mathrm{pm}$ \\
\hline 1985 & $100 \%$ & $0.9 \%$ & $25 \%$ & $34 \%$ & $143 \mathrm{pm} 31 \%$ & $10 \%[41 \%]$ \\
\hline USA & $44,193-138 \mathrm{pm}$ & $413-0.7 \mathrm{pm}$ & $12,438-141 \mathrm{pm}$ & $15,687-189 \mathrm{pm}$ & $11,940-180 \mathrm{pm}$ & $3711-180 \mathrm{pm}$ \\
\hline 2015 & $100 \%$ & $1 \%$ & $28 \%$ & $\mathrm{~m} 35 \%$ & m $27 \%$ & $8 \%[35 \%]$ \\
\hline USA \%All & $2,813,350$ & 31,786 & 92,240 & 249,938 & 903,616 & $1,535,794$ \\
\hline Deaths & $100 \%$ & $1.1 \%$ & $3.3 \%$ & $8.8 \%$ & $32.1 \%$ & $54.6 \%[87 \%]$ \\
\hline \multicolumn{7}{|l|}{ Average } \\
\hline Suicide & $148 \mathrm{pm}$ & $42 \mathrm{pm}$ & $121 \mathrm{pm}$ & 196 pm & 206 pm & $282 \mathrm{pm}$ \\
\hline$\%$ Deaths & $100 \%$ & $0.8 \%$ & $25 \%$ & $34 \%$ & $29 \%$ & $12 \%[41 \%]$ \\
\hline \multicolumn{7}{|l|}{$\begin{array}{c}\text { US } \\
\text { Suicide: }\end{array}$} \\
\hline $\begin{array}{c}\text { All } \\
\text { Death\% }\end{array}$ & $1: 1.00$ & 1.38 & 0.13 & 0.27 & 1.11 & 4.55 \\
\hline
\end{tabular}

Table 3. Average influenza to suicide deaths age-band ratios.

\begin{tabular}{|c|c|c|c|c|c|c|}
\hline $\begin{array}{l}\text { Country } \\
\text { Peak Year }\end{array}$ & $\begin{array}{c}\text { Total } \\
\text { No's-pm }\end{array}$ & $\begin{array}{c}0-14 \\
\text { No's-pm }\end{array}$ & $\begin{array}{c}15 \text { - } 34 \\
\text { No's-pm }\end{array}$ & $\begin{array}{c}35 \text { - } 54 \\
\text { No's-pm }\end{array}$ & $\begin{array}{c}55 \text { - } 74 \\
\text { No's-pm }\end{array}$ & $\begin{array}{c}75+ \\
\text { No's-pm }\end{array}$ \\
\hline \multicolumn{7}{|l|}{ Average } \\
\hline Influenza & $34 \mathrm{pm}$ & $2 \mathrm{pm}$ & $10 \mathrm{pm}$ & $21 \mathrm{pm}$ & $22 \mathrm{pm}$ & $488 \mathrm{pm}$ \\
\hline$\%$ deaths & $100 \%$ & $1.6 \%$ & $1 . \%$ & $2.5 \%$ & $15 \%$ & $80.1 \%$ \\
\hline \multicolumn{7}{|l|}{ Average } \\
\hline Suicide & $148 \mathrm{pm}$ & $42 \mathrm{pm}$ & $121 \mathrm{pm}$ & $196 \mathrm{pm}$ & $206 \mathrm{pm}$ & $282 \mathrm{pm}$ \\
\hline$\%$ Deaths & $100 \%$ & $0.8 \%$ & $25 \%$ & $34 \%$ & $29 \%$ & $12 \%$ \\
\hline \multicolumn{7}{|l|}{ \% Flue: } \\
\hline Suicide Ratio & $1: 1.00$ & $1: 0.50$ & $1: 25.0$ & $1: 1.36$ & $1: 1.93$ & 0.15 \\
\hline \multicolumn{7}{|l|}{ Average } \\
\hline Influenza & $34 \mathrm{pm}$ & $2 \mathrm{pm}$ & $10 \mathrm{pm}$ & $21 \mathrm{pm}$ & $22 \mathrm{pm}$ & $488 \mathrm{pm}$ \\
\hline Suicide pm & $148 \mathrm{pm}$ & $42 \mathrm{pm}$ & $121 \mathrm{pm}$ & $196 \mathrm{pm}$ & $206 \mathrm{pm}$ & $282 \mathrm{pm}$ \\
\hline \multicolumn{7}{|l|}{ Influenza pm: } \\
\hline Suicide Ratio & $1: 4.35$ & $1: 21$ & $1: 12.1$ & $1: 9.3$ & $1: 9.40$ & $1: 0.58$ \\
\hline
\end{tabular}


for the 15 - 34 year olds 1:1.12, more than twelve to one, and then 1:9.0 for the $35-74$ but a ratio of 1:0.58 for the elderly over 75 's, where the bulk of the influenza deaths occurred.

\section{Discussion}

We can reject the null hypothesis as there was marked difference in the age patterns of influenza and suicides, influenza deaths being mainly amongst those $>$ 55 years and the majority of suicides in people under fifty-four.

There are however some limits to this study. There was no matching of peak years between suicides and influenza peaks. Also there were few common peak years for either influenza or suicide peak years. Thus it needs to be remembered that these historical patterns covered many years, from 1979 to 2016 and societies have markedly changed, especially since the 1990's. However, the key finding that suicides occur most often in the under-fifties, exactly the reverse for influenza and current COVID-19 pandemic as reported in Wahun China [11] and in most Western countries provides a degree of external validation for the patterns found here.

It needs to be stressed that we take as self-evident the need to protect the vulnerable elderly (75+), (which is the case for two of the authors) and we strongly support the continued effort to protect front-line staff and the vulnerable, not just of age but those with pre-existing co-morbidities.

Is it noteworthy that the 'historical' patterns of influenza deaths are similar to those reported by Office of National Statistics who stated on November that $91 \%$ of COVID-19 deaths in England had occurred in people with cardiac, respiratory problems or Alzheimer's Disease and in Wuhan it was also the elderly who bore the brunt of the toll [11]. Also, in All ten countries, although having different peak years for influenza mortality, All had the same age pattern of mortality, including Norway and Portugal, representing the most and least affluent countries in the West. Equally in relation to influenza deaths, it matched the normative mortality patterns of All Causes of death in the USA.

Yet the key difference between peaks of suicides and influenza epidemics and pandemics is that the viral break-out usually ends within two or three years at the most, whereas mental behaviour disorders, related to domestic violence, child abuse and suicide persist as long as the severe socio-economic disruption continues, crucially linked to unemployment and relative poverty [6] [7] [8] [9] [10] [15] [16]. So if the IMF forecast is accurate and the economic situation post-COVID-19 will be as catastrophic as the great depression, the effects will likely last for more than a decade.

Understandably, the media focuses on the numbers of new deaths during the COVID-19 crisis, but these numbers require people to consider what percentage they represent of the many thousands, perhaps millions, of people who are infected, the as yet unknown true incidence COVID-19 infection-the vast majority eventually recovering, as in Wuhan in China where the pandemic appeared to start [11]. Indeed $95 \%$ of previous Western influenza victims were over the 
age of 55 , including $80 \%$ of over 75 's, by way of contrast $59 \%$ of people dying by suicide were under 54-year-olds. Every life has intrinsic value but when large scale "utilitarian" decisions have to be taken, it is crucial to have all the facts available to recognise levels of risk of morbidity and mortality.

The financial impact of the lockdown is unlikely to be purely financial, but could significantly increase a wide range of mental health problems both in terms of incidence, prevalence and severity [1]-[7] [15] [16] [17]. Moreover, there is unequivocal evidence that, even in the Western world, relative poverty is still strongly associated with child (0 - 4) mortality. This is reflected in two stark statistics; first the USA has both the highest relative poverty and child mortality in the West and second Britain has the third highest relative poverty and fifth highest child mortality [16]. Conversely, the four least unequal countries, Finland, Japan, Norway and Sweden, had the four lowest rates of child mortality in 2015 [16].

Governments have taken measures to mitigate the worst of the pandemic as they seek to avoid their health services being overwhelmed. Yet little effort so far has been put into militating against the potential deluge of mental health problems which will appear as part of the aftermath of the current crisis. It is likely that such a worsening of the health consequence for children and the psychologically vulnerable, combined with an already over-stretched mental health service, might well see the latter being all too easily overwhelmed. Only in the years to come, will we know if we managed to achieve the right balance between infection control and mitigation against the potentially dire socio-economic consequences of the "worst economic turn-down since the Great Depression" [13]. The question for mental health services is how to reach out to people in reactive psycho-social distress and recognise the worsening of the plight of more children living in relative poverty and whether Governments can be helped to acknowledge these longer lasting impacts of the corvid-19 a pandemic.

\section{Acknowledgements}

The authors have no vested or conflict of interests in the study. As no people or animals were involved in the project no ethical committee approval was unnecessary. Nor was there any external funding for the study. All authors were responsible for the design, development and final submission of the paper.

\section{Conflicts of Interest}

The authors declare no conflicts of interest regarding the publication of this paper.

\section{References}

[1] Holmes, E.A., O’Connor, R.C., Perry, V.H., Tracey, I. and Wessely, S. (2020) Multidisciplinary Research Priorities for the COVID-19 Pandemic: A Call for Action for Mental Health Science.

[2] Yip, P.S., Cheung, Y.T., Chau, P.H. and Law, Y.W. (2010) The Impact of Epidemic 
Outbreak: The Case of Severe Acute Respiratory Syndrome (SARS) and Suicide among Older Adults in Hong Kong. Crisis, 31, 86-92. https://doi.org/10.1027/0227-5910/a000015

[3] Demirci, Ş., Konca, M., Yetim, B. and İlgün, G. (2020) Effect of Economic Crisis on Suicide Cases: An ARDL Bounds Testing Approach. International Journal of Social Psychiatry, 66, 34-40. https://doi.org/10.1177/0020764019879946

[4] Brietzke, E., Magee, T., Freire, R.C.R., Gomes, F.A. and Milev, R. (2020) Three Insights on the Psychoneuroimmunology of Mood Disorders to be Taken from the COVID-19 Pandemic. Brain, Behavior, \& Immunity_Health. https://doi.org/10.1016/j.bbih.2020.100076

[5] Weise, J., Schomerus, G. and Speerforck, S. (2020) The SARS-CoV-2 Pandemic and an Attempted Suicide of a Patient with Delusional Disorder. Psychiatrische Praxis, 47, 218-220. https://doi.org/10.1055/a-1158-1745

[6] Pritchard, C. (1992) Youth Suicide, Gender \& Unemployment in the UK: A Comparison of Youth Suicide in the Other Countries of the European Community 1973-1988. British Journal Psychiatry, 160, 750-756. https://doi.org/10.1192/bjp.160.6.750

[7] Norström, T. and Grönqvist, H. (2015) The Great Recession, Unemployment and Suicide. Journal of Epidemiology and Community Health, 69, 110-116. https://doi.org/10.1136/jech-2014-204602

[8] Gunnell, D., Appleby, L., Arensman, E., Hawton, K., John, A., Kapur, N., Khan, M., O’Connor, R.C. and Pirkis, J. (2020) COVID-19 Suicide Prevention Research Collaboration. The Lancet Psychiatry, 7, 468-471.

[9] Sher, L. (2020) The Impact of the COVID-19 Pandemic on Suicide Rates. QJM, 113, 707-712. https://doi.org/10.1093/qjmed/hcaa202

[10] McIntyre, R.S. and Lee, Y. (2020) Projected Increases in Suicide in Canada as a Consequence of COVID-19. Psychiatry Research, 290, Article ID: 113104. https://doi.org/10.1016/j.psychres.2020.113104

[11] Zhou, F., Yu, T., Du, R., Fan, G. and Liu, Y. (2020) Clinical Course and Risk Factors for Mortality of Adult Patients with COVID-19 in Wuhan, China: A Retrospective Study. The Lancet, 395, 1054-1062. https://doi.org/10.1016/S0140-6736(20)30566-3

[12] WHO (2020) Annual Mortality Statistics. who.healthinfo.mortality.statstics.dpms.

[13] IMF (2020) The Worst Economic Down-Turn since the Great Depression. https://www.imf.org/en/News/Articles/2020/03/23/p

[14] Kposowa, A.J., Aly Ezzat, D. and Breault, K. (2019) New Findings on Gender: The Effects of Employment Status on Suicide. International Journal of Women's Health, 11, 569-575. https://doi.org/10.2147/IJWH.S216504

[15] Näher, A.F., Rummel-Kluge, C. and Hegerl, U. (2020) Associations of Suicide Rates with Socioeconomic Status and Social Isolation: Findings From Longitudinal Register and Census Data. Frontiers in Psychiatry, 10, 898. https://doi.org/10.3389/fpsyt.2019.00898

[16] Pritchard, C., Rosenorn-Lanng, E. and Williams, R. (2019) Child-Abuse-RelatedDeaths, Child Mortality (0-4) \& Income Inequality in America and Other Developed Nations 1989-91 v 2012-14: Speaking Truth to Power. Child Abuse Review, 28, 339-352. https://doi.org/10.1002/car.2599

[17] World Bank (2018) Income Inequality. http://www.world.bank.income.inequality 